\title{
The spectrum of polyneuropathies in patients infected with HIV
}

\author{
J M LEGER,* P BOUCHE, $\dagger$ F BOLGERT,* M P CHAUNU, $\ddagger$ M ROSENHEIM,$\S$ \\ H P CATHALA, $\dagger$ M GENTILINI, $\S$ J J HAUW, $\ddagger$ P BRUNET*
}

From the Clinique des Maladies du Système Nerveux, ${ }^{*}$ Service d'Explorations Fonctionnelles. Neurologie, $\dagger$ Laboratoire R. Escourolle, $\ddagger$ Service de Parasitologie et Médecine Tropicale,§ Hôpital de la Salpêtrière, Paris, France.

SUMMARY Twenty five patients with peripheral neuropathy at different stages of human immunodeficiency virus (HIV) infection are reported. Cerebrospinal fluid (CSF) findings were available in 17 cases, electrophysiology in all and a neuromuscular biopsy in 11. Of six otherwise asymptomatic HIV + patients, five had chronic inflammatory demyelinating polyneuropathy (CIDP) and one acute inflammatory demyelinating polyneuropathy (AIDP). CSF showed pleocytosis in all cases. Infiltration of the endoneurium and/or the epineurium by mononuclear cells was seen in biopsies from three cases. These six patients recovered either spontaneously, or with corticosteroids or plasmaphereses. Of five patients with AIDS related complex (ARC), three had distal predominantly sensory peripheral neuropathy(DSPN), one CIDP and one mixed neuropathy. Of 14 patients with AIDS, one had mononeuropathy multiplex and 13 painful DSPN. Electrophysiological studies were consistent with an axonopathy. Nerve biopsies in six cases showed axonal changes but surprisingly associated with marked segmental demyelination in two cases. Cell infiltration was present in nerve samples in two cases. Five patients died within six months after the onset of the neuropathy.

Various disorders of the peripheral nervous system associated with HIV infection have been reported. In nine to $16 \%$ of patients with AIDS and $20 \%$ of patients with $\mathrm{ARC}^{1-3}$ their incidence has probably been underestimated. Some recent reviews have tried to classify peripheral neuropathies and other muscular complications. ${ }^{4-7}$ On the other hand, de la Monte et at did not distinguish between the neuropathy of AIDS and the neuropathy of ARC and suggested that these syndromes be regarded as the same disease process with variable expression. We report clinical, electrophysiological and pathological findings in 25 patients who manifested a peripheral neuropathy at different stages of HIV infection.

\section{Patients}

From November 1984 to June 1988, 25 patients with HIV infection and a peripheral neuropathy were referred to the

Correspondence to: J M Leger, Clinique des Maladies du Système Nerveux, Hôpital de la Salpêtrière, 47 boulevard de l'Hôpital, 75651 PARIS Cedex 13, FRANCE.

Received 30 September 1988 and in revised form 15 May 1989. Accepted 25 July 1989
Neurological Department and the Department of Parasitology and Tropical Medicine at Salpêtriere Hospital; 18 patients were known to be seropositive before admission (for a period of from 1 to 48 months); the other seven were found to be seropositive during their admission to hospital for the neuropathic disorder.

\section{Methods}

Information included the following: age, sex, risk factor for HIV infection, duration of HIV infection and characteristics of the peripheral neuropathy. Follow up studies were conducted over a period of one month to four years.

\section{Laboratory investigations}

Serum specimens were analysed for the antibody to HIV1 by enzyme-linked immunosorbent assay, and positive sera were confirmed by Western blots. Peripheral blood CD4/CD8 ratio was available in 20 cases. CSF cellularity, protein and glucose levels were obtained in 17 cases.

Electrodiagnostic studies included examination with concentric needle electrode and nerve conduction velocities in all cases. Motor nerve conduction velocities were determined on peroneal and median nerves by surface electrodes. Sensory nerve action potential amplitude and conduction velocities were determined on sural and median nerves by near-nerve needle electrodes. Criteria for demyelinating neuropathies 
Table 1 Clinical and laboratory features in polyneuropathies of HIV-infected patients

\begin{tabular}{|c|c|c|c|c|c|c|c|c|c|c|c|c|}
\hline \multirow[b]{2}{*}{$\begin{array}{l}\text { No of } \\
\text { cases }\end{array}$} & \multirow[b]{2}{*}{$\begin{array}{l}\text { Age } \\
\text { (years) }\end{array}$} & \multirow[b]{2}{*}{ Sex } & \multirow[b]{2}{*}{$\begin{array}{l}\text { Homosex/ } \\
\text { bisex }\end{array}$} & \multirow[b]{2}{*}{$\begin{array}{l}\text { Drug } \\
\text { abuse }\end{array}$} & \multirow[b]{2}{*}{$S D$} & \multirow[b]{2}{*}{$\begin{array}{l}\text { Interval } \\
\text { (months) }\end{array}$} & \multirow[b]{2}{*}{ Type } & \multirow[b]{2}{*}{$\begin{array}{l}C D 4 / \\
C D 8\end{array}$} & \multicolumn{3}{|r|}{$C S F$} & \multirow[b]{2}{*}{$\begin{array}{l}\text { Follow up } \\
\text { (months) }\end{array}$} \\
\hline & & & & & & & & & $\begin{array}{l}\text { Protein } \\
(m g / 100\end{array}$ & $m l)$ & $\begin{array}{l}\text { Cells } \\
\left(\text { per } \mathrm{mm}^{3}\right)\end{array}$ & \\
\hline 1 & 38 & $\mathbf{M}$ & + & & AS & 0 & CIDP & - & 98 & & 17 & 48 \\
\hline 2 & 36 & $\mathbf{M}$ & + & & AS & 5 & CIDP & - & 166 & & 16 & 36 \\
\hline 3 & 31 & $M$ & + & & AS & 0 & CIDP & - & 140 & & 7 & 21 \\
\hline 4 & 38 & $\mathbf{M}$ & & & AS & 0 & AIDP & 0.5 & 400 & & 71 & 38 \\
\hline 6 & 32 & $\mathbf{M}$ & & + & AS & 0 & CIDP & 0.3 & 360 & & 44 & 0 \\
\hline 7 & 44 & $\mathbf{M}$ & + & & ARC & 3 & DSPN & 1.8 & 45 & & 0 & 24 (D) \\
\hline 8 & 40 & $\mathbf{M}$ & & & ARC & 8 & DSPN & 1.6 & & ND & & 24 \\
\hline 9 & 43 & $\mathbf{M}$ & + & + & ARC & 6 & Mixed & 0.05 & & ND & & 21 (D) \\
\hline 10 & 30 & $\mathbf{M}$ & + & & ARC & 9 & CIDP & 0.28 & & ND & & 6 \\
\hline 11 & 56 & $\mathbf{M}$ & + & & ARC & 16 & DSPN & 0.7 & & ND & & 9 \\
\hline 12 & 30 & $\mathbf{M}$ & + & & AIDS & 1 & MM & 0.04 & & ND & & 12 \\
\hline 13 & 27 & $\mathbf{M}$ & + & + & AIDS & 7 & DSPN & 0.54 & 60 & & 1 & 22 (D) \\
\hline 14 & 45 & $\mathrm{M}$ & + & & AIDS & 16 & DSPN & 0.3 & 60 & & 2 & 6 (D) \\
\hline 16 & 58 & $\mathbf{M}$ & + & & AIDS & 24 & DSPN & - & 55 & & 0.8 & 4 (D) \\
\hline 17 & 43 & $\mathbf{M}$ & + & & AIDS & 48 & DSPN & 0.6 & 58 & & 3.4 & 6 \\
\hline 18 & 39 & $\mathbf{M}$ & + & & AIDS & 24 & DSPN & 0.25 & 39 & & $22 \cdot 4$ & 6 \\
\hline 19 & 30 & $\mathrm{~F}$ & & & AIDS & 0 & DSPN & 0.16 & & ND & & 1 \\
\hline 20 & 35 & $\mathrm{M}$ & + & & AIDS & 6 & DSPN & 0.14 & & ND & & 3 \\
\hline 21 & 41 & $\mathbf{M}$ & + & & AIDS & 24 & DSPN & 1.58 & 51 & & 0.2 & 6 \\
\hline 22 & 40 & $\mathbf{M}$ & + & & AIDS & 10 & DSPN & 0.07 & 31 & & 0 & 12 \\
\hline 23 & 43 & $\mathbf{M}$ & + & & AIDS & 10 & DSPN & 0.09 & 74 & & 0 & 4 \\
\hline 24 & 58 & $\mathrm{M}$ & + & & AIDS & 21 & DSPN & 0.03 & 61 & & $1 \cdot 2$ & 4 (D) \\
\hline 25 & 29 & $\mathbf{M}$ & + & + & AIDS & 0 & DSPN & 0.22 & & ND & & 6 \\
\hline
\end{tabular}

SD: Stage of the disease; AS: Asymptomatic; ND: Not done; (D): Dead; CIDP: Chronic inflammatory demyelinating polyneuropathy; DSPN: Distal sensory peripheral neuropathy; AIDP: Acute inflammatory demyelinating polyneuropathy; MM: Mononeuropathy multiplex; Interval: time between seropositivity and first symptoms of PN.

were those defined by Kelly. ${ }^{9}$ Electrodiagnostic studies were repeated in six cases. A neuromuscular biopsy was performed on 11 patients. The peroneus brevis muscle and the cutaneous branch of the superficial peroneal nerve were removed for examination; specimens from nerve and muscle, after embedding in paraffin, were stained by hematoxylin and eosin and Masson's trichrome and examined with light microscopy. For morphometric study, semithin sections ( $2 \mu \mathrm{m}$ thick) of nerve were embedded in Epon 812 and stained with toluidine blue. The size and density of myelinated fibres per $2 \mathrm{~mm}$ of endoneurial area were determined by using a semi-automatic analyser ASM Leitz. For the preparation of teased nerves, $10 \mathrm{~mm}$ length specimens were fixed by $2.5 \%$ glutaraldehyde in 0.1 cacodylate buffer $\mathrm{pH} 7 \cdot 4$ for 24 hours, post-fixed in $2 \%$ osmium tetroxide and embedded in Epon 812.

\section{Results}

Clinical and laboratory features are reported in table 1. The 25 patients were: 23 white males, one black female and one black male ranging from 27 to 58 years, of the 24 males, 20 were homosexual/bisexual and four? were former intravenous drug users. Six were otherwise asymptomatic seropositive patients; 14 patients had AIDS as defined by the Centers for Disease Control's criteria, ${ }^{10}$ and five had ARC characterised by seropositivity for HIV, lymphadenopathy, and the absence of opportunistic infections or neoplasia. The CD4/CD8 ratio in peripheral blood was reduced in 16

Table 2 Electrophysiological features in polyneuropathies of $H I V$-infected patients

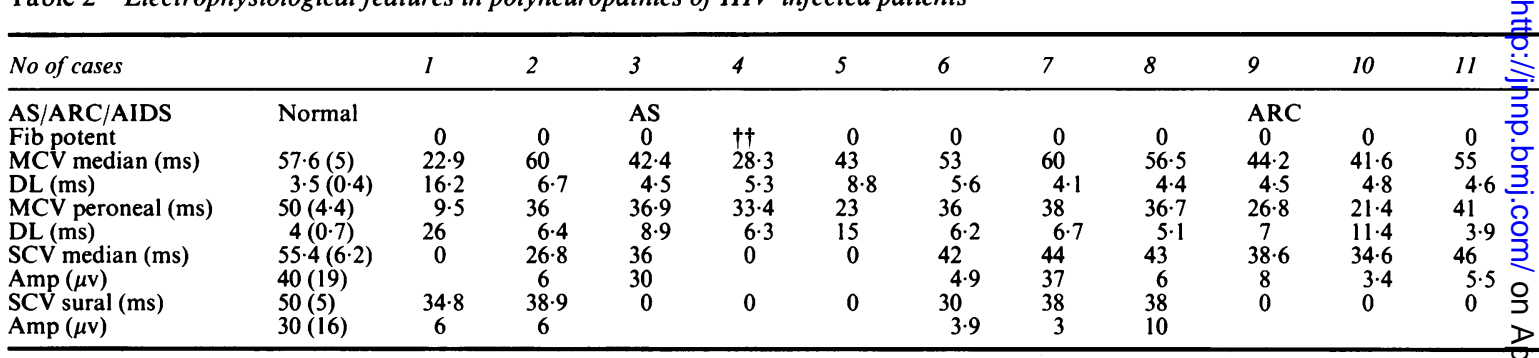

Normal: mean (SD) of $\mathbf{4 0}$ normal subjects. 
patients (less than 0.9 ) and normal in four.

\section{Group 1:}

The first group was made up of six otherwise asymptomatic patients (table 1) who had an inflammatory demyelinating polyneuropathy (IDP) with symmetrical proximal and distal weakness, relatively mild sensory symptoms and generalised areflexia. None had other systemic manifestations, but patients 3 and 5 had a progressive encephalopathy, with normal brain CT. Patient 4 had an acute evolution resembling the Guillain-Barré syndrome, requiring a tracheotomy and assisted ventilation. Patients 1, 2, 3,5 and 6 had a progressive evolution characteristic of chronic inflammatory demyelinating polyneuropathy (CIDP). CSF was examined in all cases: the total protein concentration ranged from $98-400 \mathrm{mg} /$ $100 \mathrm{ml}$, and the leucocyte count ranged from 7-71 cells $/ \mathrm{mm}^{3}$.

Electrodiagnostic studies (table 2) Motor nerve conduction velocities (MCV) were considerably reduced in the lower limbs in all six cases (especially in case 1) and in the upper limbs in three cases. Distal motor latencies were prolonged in the four limbs in all cases. Muscle action potentials (MAP) were increased in duration in five cases, normal in case 6. Sensory potentials were abnormal in all cases. Fibrillation potentials at rest were found in patient 4 later in the course of the disease. A biopsy was performed on four patients (results are given below).

Evolution The 6 patients recovered: patients 2, 3, 5 and 6 recovered spontaneously, patient 1 responded to corticosteroids and the only patient with acute IDP (case 4) had four plasmaphereses. Repeated electrophysiological examinations in three patients showed a dramatic improvement of $\mathrm{MCV}$, motor DL and sensory potentials corresponding to the clinical improvement. The follow up of patients 1, 2, 3, 4 and 5 was conducted from one to four years: they have all progressed to ARC but none has progressed to AIDS.
Group 2:

The second group was made up of five patients with ARC (table 1). The duration of the HIV infection, before the first symptoms of the peripheral neuropathy appeared, ranged from three to 16 months. All patients complained of paresthesias of the lower extremities; paresthesias of the upper extremities were present in cases 8,10 and 11 . Neurological examination showed a distal motor weakness of the lower limbs in cases 7 and 9, a distal and proximal weakness of the lower limbs in case 10. Position and pain sensations were diminished in the lower extremities in all cases and in the upper extremities in cases 8,10 and 11 . The ankle jerks were absent in cases 7, 9 and 10, diminished in the two other cases. CSF examined in case 7 was normal.

Electrodiagnostic studies (table 2) A neurogenic pattern (reduced interference pattern at full voluntary contraction) was found in the distal muscles in all cases. No myopathic patterns were present. MCV were consistent with a chronic IDP in case 10, an axonopathy in cases 7,8 and 11 , and a mixed axonaldemyelinating polyneuropathy in case 9 (which was confirmed in nerve biopsy). Sensory potentials were diminished in amplitude in the upper limbs in four cases and absent or diminished in amplitude in the lower limbs in all cases.

Evolution Follow up studies were conducted over periods of from six to 24 months. Patients 7 and 9 died two years and 21 months later respectively, both probably of a subacute AIDS encephalitis, but the neuropathy was stable. Patients 8,10 and 11 were unchanged 24, six and nine months later respectively. None progressed to AIDS.

\section{Group 3:}

The third group was made up of 14 patients with AIDS (table 1). The average duration of the disease before the first symptoms related to the peripheral neuropathy appeared, was $14 \cdot 1$ months (range: $0-48$ ). All

\begin{tabular}{|c|c|c|c|c|c|c|c|c|c|c|c|c|c|}
\hline & 13 & 14 & 15 & 16 & 17 & 18 & 19 & 20 & 21 & 22 & 23 & 24 & 25 \\
\hline $\begin{array}{l}\text { j } \\
\text {; }\end{array}$ & $\begin{array}{c}0 \\
\text { NO } \\
4 \cdot 5 \\
\text { NO } \\
11 \cdot 3 \\
40 \\
30 \\
0\end{array}$ & $\begin{array}{c}0 \\
38 \cdot 5 \\
\\
22 \cdot 3 \\
8 \\
33 \cdot 7 \\
15 \\
0\end{array}$ & $\begin{array}{c}\dagger \\
\text { ND } \\
3 \cdot 9 \\
34 \cdot 7 \\
5 \\
\text { ND } \\
0 \\
1\end{array}$ & $\begin{array}{c}0 \\
48 \\
3 \cdot 3 \\
35 \cdot 8 \\
7 \\
44 \cdot 5 \\
5 \\
36 \cdot 7 \\
1\end{array}$ & $\begin{array}{c}0 \\
42 \\
4 \\
30 \\
6 \cdot 9 \\
44 \cdot 6 \\
6 \\
0\end{array}$ & $\begin{array}{l}\text { AIDS } \\
51 \\
3 \cdot 7 \\
31 \\
4 \\
40 \\
23 \\
30 \\
1 \cdot 4\end{array}$ & $\begin{array}{c}0 \\
53 \\
3 \\
39 \\
6 \cdot 3 \\
47 \\
34 \\
38 \\
2 \cdot 3\end{array}$ & $\begin{array}{c}49 \\
3.9 \\
42 \\
5 \cdot 7 \\
41 \\
5 \cdot 3 \\
28.5 \\
2.3\end{array}$ & $\begin{array}{c}46 \\
4 \cdot 4 \\
35 \\
6 \cdot 9 \\
41 \\
13 \\
0\end{array}$ & $\begin{array}{c}47 \\
3 \cdot 8 \\
35 \\
4 \cdot 2 \\
39 \\
7 \\
30 \\
2\end{array}$ & $\begin{array}{c}0 \\
52 \cdot 6 \\
3 \cdot 8 \\
41 \\
4 \cdot 2 \\
45 \\
7 \\
40 \\
6\end{array}$ & $\begin{array}{c}0 \\
46 \cdot 2 \\
4 \\
36 \cdot 3 \\
\\
43 \cdot 2 \\
4 \cdot 8 \\
37 \cdot 5 \\
2\end{array}$ & $\begin{array}{c}0 \\
50 \\
\text { NO } \\
\\
38 \cdot 8 \\
20 \\
32 \cdot 2 \\
2\end{array}$ \\
\hline
\end{tabular}


had opportunistic infections (tuberculosis: 7, pneumocystis carinii pneumonia: 8 , Toxoplasmosis: 3 , cytomegalovirus (CMV) retinitis: 2) and four patients also had Kaposi's sarcoma. Slowly progressive dementia was present on a clinical basis in six cases. One patient had a mononeuropathy multiplex (case 12) and the electrophysiological features were consistent with an axonopathy (table 2). The 13 others complained of painful dysesthaesias of the lower extremities. Dysesthaesias of the upper extremities were present only in case 23 . Neurological examination showed a distal sensory polyneuropathy in all cases: the ankle jerks were absent in 11 cases and reduced in two cases. The knee reflexes were absent in case 25 . Only three patients presented a mild distal weakness in the lower limbs. CSF was examined in 10 cases and always found normal, except in cases 18 (leucocytosis) and 23 (protein elevation).

Electrodiagnostic findings in DSPN (table 2) On EMG examination, fibrillation potentials at rest were found in 1/9 patients. Nerve conduction studies were indicative of an axonopathy: MCV's were normal or slightly reduced in proportion to the reductions in amplitude (peroneal MCV abnormal in 10 cases and median MCV abnormal in three cases). Sensory potentials were abnormal mainly in amplitude: for the sural nerve, five patients showed no response, six had abnormal responses and two had normal responses. For the median nerve, there were six patients with abnormal responses and seven with normal responses.

Evolution Patient 12 with mononeuropathy multiplex was stable one year later. Patients 13, 14, 15, 16 and 24 died within six months. The nine other patients are alive at the time of this study, but the follow up has not exceeded one year. In two patients the neuropathy has worsened, particularly with the development of motor weakness.
Nerve and muscle biopsies (table 3: cases 1, 2, 4, 6, 9, Z $12,13,14,16,23,24)$. Detailed reports on pathological findings in patients 1, 2, 4, 9, 12 and 13 will be publisheden separately. ${ }^{11}$

Muscle biopsies A denervation atrophy was seen in every case. A mononuclear cell infiltrate, as described? below under nerve biopsy, was seen in the interstitium in five cases $(1,2,6,9,13)$.

Nerve biopsies In cases 1, 2, 4 and 6 (asymptomatic $\stackrel{\overrightarrow{\vec{\rho}}}{\frac{\overrightarrow{5}}{\sigma}}$ seropositive patients with IDP) the density of myelin-듬 ated fibres was normal or high in two cases and low $\overline{\bar{c}}$ (under $8650 / \mathrm{mm}^{2}$ ) in the two others. Teased fibre preparations showed significant segmental demyelination in all cases, associated with an axonal degenera-ç tion in three cases (which was accentuated in case $4, \overrightarrow{0}$ probably because the nerve biopsy was performed later in the course of the neuropathy). In cases 1,2 and $\vec{\sigma}$ 6 , infiltration of the endoneurium and/or the epineurium by mononuclear cells was seen; it was usually predominant around and in the walls of small vessels or whatever the type, but never involved the walls of ${ }_{-}^{N}$ arteries with a diameter above $80 \mu \mathrm{m}$. No fibrinoid $\vec{N}$ necrosis was seen. The cell infiltrate usually consisted $\vec{\omega}$ of normal lymphoid cells and monocytes.

In case 9 (ARC), the density of myelinated fibres was quite normal, but teased fibre preparations showed mixed axonal-demyelinating changes consis. tent with the electrophysiological findings. Cell infit trates were present in the endoneurium and tie $\frac{\mathbb{S}}{3}$ epineurium, with involvement of vascular walls small vessels.

In cases 12, 13, 14, 16, 23 and 24 (AIDS with either mononeuropathy multiplex or DSPN) the density of $\subseteq$ myelinated fibres was very high in case 16 indicating a marked regeneration and low in the five others. Teased fibre preparations showed a predominantly axonal degeneration in four cases and a predominantly

Table 3 Nerve and muscle biopsies

\begin{tabular}{|c|c|c|c|c|c|c|}
\hline \multirow{2}{*}{$\begin{array}{l}\text { No } \\
\text { of } \\
\text { cases }\end{array}$} & \multirow{2}{*}{$\begin{array}{l}\text { Morphometry } \\
\text { Density of } \\
\text { myelinated } \\
\text { fibres/mm }{ }^{2}\end{array}$} & \multicolumn{2}{|c|}{ Teased fibres } & \multirow[b]{2}{*}{$\begin{array}{l}\text { Segmentary } \\
\text { demyelination }\end{array}$} & \multicolumn{2}{|c|}{$\begin{array}{l}\text { Inflammatory cells } \\
\text { infiltrates }\end{array}$} \\
\hline & & Normal & $\begin{array}{l}\text { Axonal } \\
\text { degeneration }\end{array}$ & & Muscle & Nerve \\
\hline $\begin{array}{l}\text { AS } \\
1 \\
2 \\
4 \\
6 \\
\text { ARC }\end{array}$ & $\begin{array}{rl}7 & 481 \\
9 & 425 \\
2 & 136 \\
10 & 136\end{array}$ & $\begin{array}{l}\% \\
33 \\
86 \\
18 \\
34\end{array}$ & $\begin{array}{r}\% \\
32 \\
3 \\
64 \\
40\end{array}$ & $\begin{array}{l}\% \\
25 \\
11 \\
14 \\
26\end{array}$ & $\begin{array}{l}+ \\
+ \\
- \\
+\end{array}$ & $\begin{array}{l}+ \\
+ \\
+\end{array}$ \\
\hline $\begin{array}{l}9 \\
\text { AIDS }\end{array}$ & 6011 & 34 & 36 & 30 & + & + \\
\hline $\begin{array}{l}12 \\
13 \\
14 \\
16 \\
23 \\
24 \\
\text { Normal }\end{array}$ & $\begin{array}{r}1670 \\
3978 \\
5400 \\
13500 \\
7270 \\
7581 \\
8650 \pm 730\end{array}$ & $\begin{array}{l}40 \\
47 \\
30 \\
49 \\
29 \\
39\end{array}$ & $\begin{array}{l}60 \\
46 \\
64 \\
48 \\
29 \\
16\end{array}$ & $\begin{array}{r}0 \\
7 \\
16 \\
3 \\
42 \\
45\end{array}$ & $\begin{array}{l}\overline{+} \\
\overline{-} \\
- \\
-\end{array}$ & $\begin{array}{l}+ \\
+ \\
- \\
- \\
-\end{array}$ \\
\hline
\end{tabular}


segmental demyelination in two cases (23 and 24). Cell infiltrates were found in cases 12 and 13 (where the duration of the HIV disease was one and seven months respectively) and absent in cases 14, 16, 23 and 24 (where the duration of the HIV disease was 16 months, two years, 10 months and 21 months respectively).

\section{Discussion}

Peripheral nervous system (PNS) manifestations of AIDS and ARC have become more and more widely recognised, ${ }^{72-18}$ but there are relatively few papers on the clinical features and the natural history of peripheral neuropathy. Systematic electrophysiological studies have been conducted in HIV patients and have shown a high frequency of abnormalities. ${ }^{19-21}$ Nerve biopsies $^{1122}$ have shown either axonal or demyelinating changes, and frequent mononuclear cell infiltration in the early stages of the HIV infection.

Based on clinical and laboratory criteria, several distinct types of peripheral neuropathies have been identified but questions persist regarding the correlations with the HIV-infection stages and the electrophysiological and pathological findings. In our study, otherwise asymptomatic patients presented an inflammatory demyelinating polyneuropathy (IDP), mainly subacute. These findings were strikingly similar to those previously reported..$^{13182324}$ Two features differentiate this type of neuropathy from common IDP: CSF pleocytosis, associated with high protein level, and inflammatory cell infiltrates in nerve biopsies. The predominant cell type has been found to be CD8 positive. ${ }^{1317}$ IDP occurs at relatively early stages of the disease, before severe immunodeficiency, and probably results from immunopathogenic mechanisms (macrophage-mediated demyelination) rather than direct viral infection. ${ }^{13}$ In three other published cases, IDP has been shown to be a symptom of HIV seroconversion. ${ }^{25}{ }^{26}$ For other authors, the presence of cytomegalovirus (CMV) in the Schwann cells in previously published cases of Guillain-Barré syndrome associated with HIV infection, ${ }^{27}$ increases the likelihood that CMV may play a causative role in some patients. IDP usually improves spontaneously with corticosteroids or plasmaphereses ${ }^{713}$ but response to treatment is not uniform and the absence of response may be a sign of poor prognosis.' In our series, the long-term prognosis was good.

In ARC the spectrum of the peripheral neuropathy was heterogeneous, usually distal symmetrical axonopathies, but also mixed axonal-demyelinating polyneuropathy and chronic IDP. Prognosis seems to be worse than in otherwise asymptomatic patients. In our series most patients failed to progress satisfactorily and some of them developed AIDS. Four similarly affected patients of Lipkin et $a l^{18}$ died less than one year after the onset of the neuropathy. Five of six patients reported by Cornblath et a $l^{9}$ later developed AIDS (on average, 7 months later).

Of the AIDS patients in our study, only one showed a multiple mononeuropathy. The clinical, electrophysiological and pathological features of this case were similar to those reported by Lipkin et al. ${ }^{18}$ Electrophysiological studies show more widespread evidence of peripheral nerve disorder than expected from the sensory symptoms alone, and nerve biopsy specimens point to a severe axonopathy accompanied by perivascular inflammatory infiltrates in most cases. A second form of vasculitic-type multiple mononeuropathy has been reported by Said et $a l^{30}$ and Lange et al: ${ }^{7}$ in nerve biopsies a necrotising vasculitis similar to that seen when periarteritis nodosa was present.

A predominantly sensory painful polyneuropathy affected the other AIDS patients of our series. This type of neuropathy was reported in the first publications ${ }^{23}$ and is probably the most common PNS disease in HIV infection, affecting up to $30 \%$ of patients with AIDS. ${ }^{29}$ It is associated with profound immunosuppression and multiple opportunistic infections and sometimes malignancies. Seven of our patients took isoniazid for a pulmonary or generalised tuberculosis, but their neuropathy was no different from those of other patients and had generally begun before this treatment. The patients complain of pain in their feet and present signs of distal symmetrical peripheral neuropathy on clinical examination. CSF is usually normal. Electrophysiological studies suggest and teased nerve fibres studies usually confirm an axonopathy. We were surprised to find a predominantly segmental demyelination in $2 / 5$ patients who had the same symptoms and the same course than the others. In addition, mononuclear cell infiltrates seem to be rare in muscle and nerve biopsies performed in the DSPN of AIDS. ${ }^{11}{ }^{17}$ Only $1 / 5$ of our patients had cell infiltrates in nerve biopsy but we noted that, in this case, the HIV disease developed for only seven months, which could explain the presence of immunopathogenic features. Inflammatory cell infiltrates were also reported in this type of peripheral neuropathy by Bailey et al. ${ }^{31}$ Prognosis of the DSPN of AIDS is poor: $5 / 12$ patients of our study and 18/26 patients reported by Cornblath $e t a l^{9}$ died within six months of the onset of the neuropathy. The cause of this syndrome is subject to conjecture. Rance $e^{2} a^{\beta^{2}}$ reported a selective gracile tract degeneration in all four necropsy cases, and mild dorsal root ganglioneuritis in one case. These cases suggested a direct retroviral infection of lumbosacral dorsal root ganglion cells with subsequent central-peripheral distal axonal degeneration. However, De la Monte et al proposed that the axonopathy might be secondary to 
T-cell and macrophage-mediated tissue destruction in the peripheral nerve. Further studies are necessary to know if these neuropathies are due to a direct retroviral action or to multiple causes (vitamin deficiency, side effects of drugs, opportunistic infections).

We thank Professors Castaigne, Laplane, Lyon-Caen and Chain for allowing us to study their patients, $\mathrm{Dr}$ Ratinahirana for performing the teased nerve fibres and Dr Dohin for his help in the follow up of the patients.

\section{References}

1 Dalakas MC. Neuromuscular complications of AIDS. Muscle Nerve 1986;9:92.

2 Levy RM, Bredesem DE, Rosenblum ML. Neurological manifestations of the acquired immunodeficiency syndrome (AIDS): experience on UCSF and review of the literature. $J$ Neurosurg 1985;62:475-95.

3 Snider WD, Simpson DM, Nielsen S, Gold JWM, Metroka CE, Posner JB. Neurological complications of acquired immune deficiency syndrome. Ann Neurol 1983;14:403-18.

4 Cornblath DR. Treatment of the neuromuscular complications of human immunodeficiency virus infection. Ann Neurol 1988; 23(suppl):S88-91.

5 Dalakas MC, Pezeshkpour GH. Neuromuscular diseases associated with human immunodeficiency virus infection. Ann Neurol 1988;23(suppl):S38-48.

6 Parry GJ. Peripheral neuropathies associated with human immunodeficiency virus infection. Ann Neurol 1988;23(suppl):S49-53.

7 Lange DJ, Britton CB, Younger DS, Hays AP. The neuromuscular manifestations of human immunodeficiency virus infections. Arch Neurol 1988;45:1084-8.

8 de la Monte SM, Gabuzda DH, Ho DH, et al. Peripheral neuropathy in the acquired immunodeficiency syndrome. Ann Neurol 1988;23:485-92.

9 Kelly JJ. The electrodiagnostic findings in peripheral neuropathy associated with monoclonal gammopathy. Muscle Nerve 1983; 6:504-9.

10 Centers for Disease Control. Revision of the case definition of acquired immunodeficiency syndrome for national reportingUnited States. $M M W R$ 1984;34:373-5.

11 Chaunu MP, Ratinahirana H, Raphael M, et al. The spectrum of changes on 20 nerve biopsies in patients with HIV infection. Muscle and Nerve 1989;12:452-9.

12 So YT, Holtzman DM, Abrams DI, Olney RK. Peripheral neuropathy associated with acquired immunodeficiency syndrome. Arch Neurol 1988;45:945-8.

13 Cornblath DR, McArthur JC, Kennedy PGE, Witte AS, Griffin JW. Inflammatory demyelinating peripheral neuropathies associated with human T-Cell lymphotropic Virus Type III infection. Ann Neurol 1987;21:32-40.

14 Ho DD, Rota TR, Schooley RT, et al. Isolation of HTLV-III from cerebrospinal fluid and neural tissues of patients with neuro- logic syndromes related to the acquired immunodeficiency $\bar{Z}$ syndrome. New Engl J Med 1985;313:1493-7.

15 Léger JM, Chaine P, Bouche P, Bolgert F, Cathala HP, Brunet P. Neuropathies périphériques en relation avec l'infection par@ HIV. Presse Med 1988;16:1658.

16 Léger JM, Bouche P, Bolgert F, Chaunu MP, Cathala HP, Hauw JJ, Brunet $P$. The spectrum of polyneuropathies in patients ${ }_{C}$ infected with HIV. Neurology 1988;38(suppl):349-50.

17 Leport C, Chaunu MP, Sicre J, Brun-Vezinet F, Hauw JJ, Vilde $\stackrel{\overbrace{}}{\supset}$ JL. Neuropathie peripherique en relation avec l'infection par le rétrovirus LAV/HTLV-III. Press Méd 1987;16:55-8.

18 Lipkin WI, Parry G, Kiprov D, Abrams D. Inflammatory neuropathy in homosexual men with lymphadenopathy. Neurology 1985;35:1479-83.

19 Gastaut JA, Gastaut JL, Pellissier JF, Finaud M, Tapko JB, 응 Gamby T, Carcassonne Y. Neuropathie périphérique et infec-음 tion par le rétrovirus HIV. Presse Med 1987;16:1057.

20 Smith T, Jakobsen J, Gaub J, Helweg-Larsen S, Trojaborg W. Clinical and electrophysiological studies of human immunodeficiency virus-seropositive men without AIDS. Ann Neurol ผ 1988;23:295-7.

21 Vishnubhakat SM, Beresford HR. Prevalence of peripheral $\overrightarrow{0}$ neuropathy in HIV disease. Prospective study of 40 patients. Neurology 1988(suppl 1):350.

22 Chaunu MP, Henin D, Duyckaerts C, et al. Peripheral nerve changes in 4 cases of AIDS and 1 case of ARC. Muscle Nerve? 1986(suppl 5):99.

23 Dehen H, Boulu P, Fenelon G, et al. Neuropathie périphérique ơ type polyradiculonévrite inflammatoire au cours d'anomalies $N$ immunitaires évoquant le syndrome d'immunodéficit acquis. $\overrightarrow{\mathrm{N}}$ Presse Med 1985;14:226.

24 Mishra BB, Sommers W, Koski CK, Greenstein JI. Aç્ $\vec{\omega}$ inflammatory demyelinating polyneuropathy in the acquire⿻ immune deficiency syndrome. Ann Neurol 1985;17:131-2. 옹

25 Piette AM, Tusseau F, Viognon D, et al. Acute neuropat coincident with seroconversion for LAV/HTLV-III. Langet 1986;i:852.

26 Vendrell J, Heredia C, Pujol M, Vidal J, Blesa R, Graus $\mathscr{S}$. Guillain-Barré syndrome associated with seroconversion for anti-HTLV-III. Neurology 1987;37:544.

27 Bishopric G, Bruner J, Butler J. Guillain-Barré syndrome w安 cytomegalovirus infection of peripheral nerves. Arch Pathol $L \vec{a} \vec{b}$

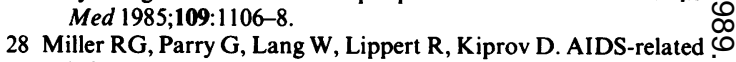
inflammatory polyradiculoneuropathy: prediction of response to plasma exchange with electrophysiologic testing. Muscle Nerve 1985;8:626.

29 Cornblath DR, McArthur JC. Predominantly sensory neuropathy in patients with AIDS and AIDS-related complex. Neurology 1988;38:794-6.

30 Said G, Lacroix C, Andrieu JM, Gaudouen C, Leibowitch J. Necrotizing arteritis in patients with inflammatory neuropathy $\overrightarrow{\bar{O}}$ and human immunodeficiency Virus (HIV-III) infection. 3 Neurology 1987;37(suppl 1):176.

31 Bailey RO, Baltch AL, Venkatesh R, Singh JK, Bishop MB. Sensory motor neuropathy associated with AIDS. Neurology 1988;38:886-91.

32 Rance NE, McArthur JC, Cornblath DR, Landstrom DL, Griffin JW, Price DL. Gracile tract degeneration in patients with? sensory neuropathy and AIDS. Neurology 1988;38:265-71. 